\title{
Knowledge in Higher Education from the Book "Pedagogy of Autonomy" by Paulo Freire
}

\author{
Antonio José Müller*, Meike Marly Schubert \\ FURB - Univerisdade Regional de Blumenau, Brazil \\ *Corresponding author's email: antoniomuller2 [AT] hotmail.com
}

\begin{abstract}
This article aims to analyze the essential knowledge for higher education described in the work Pedagogy of Autonomy of Paulo Freire (1996). Higher education must ensure professional training, but it needs to rescue the scientific and humanistic training that has been left out of teaching, which requires knowledge essential to teaching for the critical educational practice that lead learners to autonomy to transform their own reality. It consists of a bibliographical research, based on the reading of Paulo Freire's Pedagogy of Autonomy, which deals with knowledge essential to educational practice. It permeates the approach of the "being" teacher to the critical and ethical educational practice; research in the construction of autonomous and transformative thinking of reality itself. The teaching knowledge proposed by Paulo Freire allows the critical educational practice, ethics that leads to the autonomy of the student's thinking.
\end{abstract}

Keywords---- Educational practice. Higher education. Knowledge.

\section{INTRODUCTION}

This article aims to analyze the essential knowledge for higher education described in the work Pedagogy of Autonomy of Paulo Freire (1996). Teaching should lead learners to understand social transformations. And in this context, the knowledge of teaching is fundamental to the critical educational practices that lead learners to autonomy. Therefore, higher education should ensure professional training and also rescue the scientific and humanistic training that was left out of teaching, which according to Pimenta and Almeida (2011) causes academics not to receive adequate intellectual training to understand the world, society and history, which is expected from the Teaching Institutions.

This context has contributed to the fact that some teachers in higher education consider education as irrelevant to the development of the relationship between teaching and learning. In their view, content and professional experience in the area of teaching in higher education, reinforced by LDB (1996), which affirms that the formative processes for teaching in higher education are characterized by preparation in postgraduate courses and there is no specific training for teaching and learning processes.

According to Pimenta and Almeida (2011), this makes the teacher "scientifically unaware of the constituent elements of the teaching action, such as planning, class organization, teaching methodologies and strategies, evaluation and peculiarities of teacher interaction -student". According to the authors, this shows the need to rethink the pedagogical dimension, which of course is not an easy job considering the habitual profile of the teacher of higher education.

Higher education requires that the teacher understands the construction of his / her teaching identity, that is, that he / she sees himself as a teacher. According to Carlos Marcelo (2009) teacher identity is how the teacher understands himself as a professional that builds on what the individual perceives and seeks as a process of building a subject in the personal and professional aspects. Pimenta (2002) also shows that the professional identity is still built in the initial graduation, by the academic experiences, by the knowledge and knowledges experienced in its teaching practice. That is, it is an interaction between personal, social and professional life, linked to the development of subjective and objective elements that permeate personal and professional life.

For Pimenta (2002) the construction of new knowledge is interspersed between the learning that has already been acquired in the initial formation and practical experience and generate different behaviors which makes perceptible dimensions that oppose the idea that it suffices the technical preparation of the teacher, but it seems that there is an urgent need for preparation on the pedagogical aspects of the teaching profession. 
The training of this teacher should be based on the various knowledges that enable a pedagogical practice that leads academics to scientific, professional and, above all, humanistic knowledge. In this sense Freire (1996) proposes that it is necessary to have an educational practice of the teacher with reflection in favor of the autonomy of the learner that leads him to think critically. For this, Freire understands that there must be the extinction of the neutrality of practice that is a predominant ideology in which information is deposited only to students without promoting a formation capable of developing criticality, in which the ethics of the human being would be a way to counteract adverse social reality; that values and extends the deprived practices of neutrality, because it is not simply a reproductive of the dominant mercantilist ideology but seeks social transformations through educational practices.

To achieve an educational practice suggested by Freire, there is a need for essential knowledge in teaching. In this way, this study brings an approach of these essential knowledges to the superior teaching with scope on being the teacher for the critical and ethical practice; and research in the construction of autonomous and transformative thinking of reality itself. Freire talks about the formation of the teacher and the necessary knowledge to an educational practice for a critical educational practice. This is what he calls critical pedagogy, made by the progressive or critical teacher. For Freire (1996) teaching must lead learners to their survival in a world that is possible for social transformation. And in this context it points out knowledge that must be obligatory to the organization of the teacher training, which are fundamental the critical educational practice that takes the students to the autonomy. Our research has as field of investigation these knowledge presented as possibilities for discussion of the problematic that we point at teaching when we look at the University in its role in the students development.

\section{THE KNOWLEDGE IN HIGHER EDUCATION}

Higher education defines the conception that suffices to the teacher specific knowledge of the content of the area allied to professional experience, which would be enough to teach in higher education. In this context, where the pedagogical training of the teacher seems to be decontextualized from the teaching profession, the discussion about this question arises that indisputably encompasses the teaching knowledge.

Tardif (2007, p.36) defines "teacher knowledge as plural knowledge; these constitute the teachers from their academic life, in the initial and continued formation ". The term 'know' can encompass information, beliefs, skills, and aptitudes related to a particular profession. For Nóvoa (2007) the identity that each individual constructs as an educator anchors itself in a unique balance between the personal attributes and the professional trajectory, built with the time. Understanding professional identity as a career-based construct, Freire (1996) proposes a critical educational practice based on the essential knowledge understood from the fact that we are inconclusive what allows us to evolve and that advances both in personal and in the teaching practice. Freire emphasizes that the profession demands seriousness because it understands the act of teaching also as a political act that instigates the student to think critically making him more creative and more curious, which leads him to want to learn more about the object of study ending the human conditioning of deforming banking education.

\subsection{The "being" teacher for a critical and ethical educational practice}

In a critical educational practice, the teacher not only transfers knowledge but also arouses the student's curiosity about epistemological knowledge, preventing a superficial teaching and a critical reflection of the relation theory and practice to generate student autonomy that is enriched according to Freire (1996), when the teacher in his practice manages to bring to the classroom the discussion about the reality in which the student is inserted. Dialogue is the learning movement capable of promoting the criticality of academics, for Freire (1996, p.52): "before any attempt to discuss techniques, materials, methods for such a dynamic classroom, it is necessary to witness to the students a certain behavior when discussing a fact and exposing their position".

Freire (1996, p.64) affirms that the teacher's speech should be the exercise of his practice. "As important as the teaching of content is my coherence between what I say, what I write and what I do what becomes an ethical testimony. For teaching it becomes necessary an inseparable ethics of the practice in the relations with the students by the way we stand with respect to the thought of others that is indispensable for human coexistence.

Still in this direction we are faced with the question of acceptance of the new to what is meant to welcome the new social issues increasingly present as discrimination as to race, gender, social class; the issues of cultural plurality; the preservation of the environment, etc. Here we emphasize respect based on dialogue as mediation being one of the most important knowledge in this educational practice in different cultural and intellectual conditions favoring freedom of expression that cannot be stopped by authoritarianism but in a perspective based on generosity in sharing knowledge.

This educational practice proposed by Freire wants, above all, to show that there is a possibility of no longer allowing market dictatorship in education, and that only the teacher's awareness as a being and his teaching practice can 
promote through dialogue and willingness the students. Considering that each teacher is composed singularly it is noted that the appropriation of these knowledges are significant for the contribution in the formation of the teaching professional in which not only the technical knowledge is valued, but one begins to think about the teacher who elaborates and recreates his knowledge in confrontation with their learning and experiences in the different contexts of professional performance.

There is knowledge necessary for the educational practice for the students to become autonomous. The teacher needs to reflect his practice, because to train is not just to train or transfer knowledge as it happens in banking education. Critical educational practice makes it possible for autonomy to turn from being a student to being educated. In order for the teacher to incorporate this critical educational practice, Freire considers some essential knowledge of this transforming practice. But for this practice to achieve its goals, it must first be understood by the teacher himself. The teacher also needs to be and incorporate this knowledge, because he is also an unfinished being.

In proposing to the teacher to reflect his practice, Freire is worried about the ethical attitude of each one; having a critical view does not mean merely rebelling, or agreeing to wars, with acts of terrorism, for example. He demonstrates a concern and stresses that we must remain ethical in the exercise of the teaching task. Therefore, the proposal is a critical reflection on teachers about these ideas that will resonate in the minds of teachers.

For this reason, he emphasizes a lot, that ethics is present in every aspect of our lives. As in the educational act, what demands that the teacher be ethical? To be ethical for Paulo Freire is to disagree with the domination and interests of the market in the manipulation of the people through public education. Here he speaks of the universal ethics of the human being, which should be an inseparable ethics of educational practice; all content in the classroom passes through the position of the teacher in front of his explanation and point of view.

In fact, Freire proposes to rescue an ethic that seems to have been left aside in relation to what is taught. But this happened because of the perversity that makes everyone agree with education as it is, how it presents itself to society, and what meets the demand of the market. It seems that there is an ethic in which everyone agrees, "in which certain behaviors are considered normal" in a hypocritical way, such as questions related to gender, race, social class, for example, or that the school is anyway, that content should be the same, etc.

Ethics have to be worked on with children, young people and adults throughout the educational practice. How to do this? How to bring ethics to learners? Freire proposes to bear witness to ethics for our educational practice in our relations with students. But for this we also have to be ethical, we have to be a teacher. It is the way in which the teachers we position with respect to the contents, to the information that we discussed in the classroom with our students.

This attitude has to be thought when we think about a text, about an author, about the situation that is happening in the school, in the community, with the other teacher who is in the next class, etc. Ethics is not only about agreeing or not agreeing, but it is mainly about using our arguments to justify the points of view, knowing that my opinion will not be the only one that is right, that has value to other people.

The teacher must convey to the students the confidence that their opinion respects the thought of others. Paulo Freire emphasizes at all times that educational practice is a human action, therefore inseparable from ethical practice, which is indispensable for human coexistence. Being ethical does not mean naiveté or idealism before the world. Being ethical is a human vocation because at last we are human.

This is how it should be; it is human nature to be, which makes us unique and unique, in which its presence and the presence of the other in the world in which both coexist. The awareness that one has of being in the world causes the individual to inevitably assume ethics in their coexistence. Freire also does not want this idea to be understood in an optimistic way, which for many may seem something very dreamy, a daydream.

In this sense he regrets, because ethics is part of the constitution of the human being and his conscience in the world, as already pointed out previously. For the author, the ethics of the human being would be a way of confronting the neoliberal discourse that draws social reality today, which seeks to immobilize people to continue to think that it is so, that we must all adapt to this reality, which thinking in this way impoverishes and scares the human being.

It is worth emphasizing that the essential knowledge pointed out by Freire, in his view, will show if the teacher's practice is a progressive or critical educational practice; or is still part of a conservative teacher's practice. For teachers to be effective, the teacher must first understand that theory and practice must go hand in hand and that is why there is a critical reflection that happens in this relation. When this occurs, we are preventing only a transmission of knowledge, because of create the possibility of building that knowledge, from your own understanding.

\subsection{Research in the construction of autonomous and transformative thinking of reality itself}


In order to construct a thought, not single information is enough; the student to create autonomy must be led to be a researcher, who discovers several sources about the same information. This process of researcher contributes to his constructing his thinking, aligning the initial idea of the teacher with his research, and finally with what he elaborated mentally as his own creation. This generates autonomy of thought.

This construction of knowledge is enriched, according to Freire, when the teacher in his practice manages to bring to the classroom the discussion about the reality in which the student is inserted, taking care here not to neglect the social condition of the students, but rather to make the different realities confront the unilateral visions that the programmatic contents do not share in the textbooks.

The teacher cannot allow common sense to be the only answer to questions, because the criticality expected of the teacher is precisely to "break" common sense around the world that we know, and they want us to continue to believe that it must be anyway. Educational practice also requires example, the teacher who speaks one thing and acts from another, certainly loses the confidence of his students; that is; the educational practice must be above all a testimony of what I think, speak and do, so that I can be a living example to the students.

In this direction, we come to the question of acceptance of the new, which refers to accepting the new social issues now increasingly present in everyday school life, such as discrimination issues such as race, gender, social class; questions of cultural plurality; the preservation of the environment, etc.

Freire considers dialogue as communication that is necessary between the teacher and the students. The whole practice presented here is based on having a teacher who enables the student to think right, and to think about it is a question of ethics of the human being.

In Freire's progressive educational practice, it is also up to each teacher's commitment to assume his or her cultural identity and how to lead students to this same understanding, which happens through the relationships that are established between one another and the conditions as they are conducted. For this, this teacher must be aware of its incompleteness, because only in this way, will be able to evolve as its previously pre-established conceptions; being an unfinished being allows me to evolve and advance both in personal aspects and in teaching practice.

It is in this way that the educational practice must be conducted, as something in permanent construction, because knowledge is not something finished and finished, but it is being constituted with educator and educated ones able to learn instigated by the curiosity. For this, the author emphasizes respect as one of the most important knowledge in this progressive educational practice. The respect that goes from the child to the elderly; the respect for the unfinished beings that we are, and the one that takes us to different cultural and intellectual conditions. '

It is a respect for freedom of expression that cannot be restrained by authoritarianism that does not fit into a practice based on dialogue and discussion of ideas based on freedom of expression. As stated by the author, the educational practice should reflect what the teacher speaks to what he does, so common sense is necessary as an exercise in which I assume and take positions guided by ethics and coherence, which it does not seem to be extreme and too licentious.

As Freire brings us, teaching requires humility, tolerance and struggle in favor of teaching and the rights of educators for whom the school community and public authorities must be aware, above all, to understand that everyone must have dignity. But the struggles cannot cause the joy and motivation of this work to be lost. Freire (1996) brings one of the essential knowledge in a critical educational practice that says that teaching is a human specificity.

Being a teacher and teaching infers an authority not in the sense of authoritarianism, or as sole owner of knowledge. The teacher's authority is to mediate the relationships established with the educated and to mediate the constructions of shared knowledge, giving voice and voice to the participation of all, in an environment in which respect for the unfinished beings who advance in knowledge prevails.

The authority of the teacher in a progressive perspective is based on competence and generosity in sharing knowledge. As a progressive teacher, he seeks commitment in educational practice because he is not neutral in the situations that are posed; I assume the posture with clear opinions so that the learners perceive the presence of the teacher, not only physically, but that the "think" is made visible to the students.

\section{FINAL CONSIDERATIONS}

Higher education is immersed in this reality in which it seeks to discuss teaching by confronting its role as producer of epistemological knowledge and training of human resources in the labor market and the need for training that meets the new society. In order to do so, the need for pedagogical training of the teacher who is qualified to teach from an area of 
his / her specialty and professional experience without considering pedagogical training is increasingly discussed. There are specific knowledges that are essential in the process of teaching learning.

Faced with the questions found in teaching, we can see in Freire's ideas contributions to broaden and enrich this discussion about teaching in higher education in which we can highlight the "being" teacher for a critical and ethical educational practice and research in the construction of autonomous thinking and transforming one's own reality One of the crucial points for Freire is that teachers understand education as the means by which it is possible to raise people's awareness of their condition in a commodified society.

That is why it presupposes a critical educational practice as a way capable of higher education to train competent professionals in its field of activity, but above all, to understand the society in which they live and are part of it. The teacher to understand that the teaching action is not based only on knowledge and technical skills generates a different conduct in which there are make relevant the knowledge linked to teaching proposed for the autonomy of students.

\section{REFERENCES}

- $\quad$ BRASIL. Ministério da Educação. Lei no 9.394, de 20 de dezembro de 1996. Disponível em: <http://portal.mec.gov.br/sesu/arquivos/pdf/lei9394.pdf>. Acesso em: 24 dez. 2017.

- $\quad$ FREIRE, Paulo. Pedagogia da Autonomia. Saberes necessários a prática educativa. EGA São Paulo/SP, 1996.

- MARCELO, Carlos. Desenvolvimento profissional docente: passado e futuro. Sísifo. Revista de Ciências da Educação. 2009, 7-22. Consultado em: julho de $2018 \mathrm{em}$ http://sisifo.fpce.ul.pt.

- NÓVOA, A. Os professores e as histórias da sua vida. In: NÓVOA, A. (Org.). Vidas de professores. 2. ed. Lisboa: Porto Editora, 2007

- $\quad$ PIMENTA, S. G. (Org.). Saberes pedagógicos e atividade docente. 3. ed. São Paulo: Cortez, 2002.

- $\quad$ PIMENTA, Selma Garrido; ALMEIDA, Maria Isabel. Pedagogia Universitária: caminhos para a formação dos professores. São Paulo/SP: Cortez, 2011.

- $\quad$ TARDIF, M. Saberes docente e formação profissional. 6. ed. Petrópolis: Vozes, 2006. 